\title{
Letter to the Editor: Challenging one sensor method for screening dairy cows for reduced methane emissions
}

\author{
P. Huhtanen ${ }^{* 1}$ and A. N. Hristov† \\ *Department of Agricultural Science, Swedish University of Agricultural Sciences, S-90183 Umeå, Sweden \\ †Department of Animal Science, The Pennsylvania State University, University Park 16802
}

Selective breeding is suggested as a mitigation strategy to reduce enteric methane $\left(\mathrm{CH}_{4}\right)$ emission by dairy cows. Ranking of animals for genetic selection for low $\mathrm{CH}_{4}$ emitting potential requires reliable and cost-effective measurements from a large number of animals in farm conditions. As an international group of scientists pointed out "... the need for high throughput methodology, e.g. for screening large numbers of animals for genomic studies, does not in itself justify the use of methods that are inaccurate, imprecise, or biased" (Hammond et al., 2016). Recently, van Engelen et al. (2018) used infrared sensors installed in automatic milking systems; that is, the "sniffer" method, to measure $\mathrm{CH}_{4}$ and carbon dioxide $\left(\mathrm{CO}_{2}\right)$ concentrations in exhaled air. However, $\mathrm{CH}_{4}$ concentration measured by the sniffer method was poorly correlated with $\mathrm{CH}_{4}$ flux in a study conducted on 2 research farms (Huhtanen et al., 2015). In laboratory studies, the distance from the sampling point had a strong influence on measured $\mathrm{CH}_{4}$ concentration (Huhtanen et al., 2015; Wu et al., 2018), and in the farm-scale study, head position was strongly related to $\mathrm{CH}_{4}$ concentration (Huhtanen et al., 2015). Wu et al. (2018) also suggested a systematic error resulting from between-cow variation in exhalation rate. van Engelen et al. (2018) tested the sensors in respiration chambers before they were installed on commercial farms. This is not an appropriate test of the sniffer method, because eructations influence gas concentrations much less in the chamber than under barn conditions. In addition, airflow from the chamber to sensors invalidates the sniffer test used. In the study of van Engelen et al. (2018), both the mean and standard deviation (SD) of the $\mathrm{CH}_{4}: \mathrm{CO}_{2}$ ratio were biologically unrealistic. The mean $\mathrm{CH}_{4}: \mathrm{CO}_{2}$ ratio of 0.17 (volume basis) was about 2-fold greater than that reported by Aubry and Yan (2015) from respiration chamber studies with lactating and growing cattle fed different diets. A dairy cow $(\mathrm{DMI}=20 \mathrm{~kg} / \mathrm{d}, \mathrm{ECM}$ yield $=30$

\footnotetext{
Received March 6, 2018.

Accepted June 8, 2018.

${ }^{1}$ Corresponding author: pekka.huhtanen@slu.se
}

$\mathrm{kg}$ ) produces about $130 \mathrm{MJ}$ of heat and emits about $5,800 \mathrm{~L}$ of $\mathrm{CO}_{2}(22.8 \mathrm{~kJ} / \mathrm{L})$, which would correspond to about $710 \mathrm{~g}$ of $\mathrm{CH}_{4} / \mathrm{d}$, if the gas ratio were 0.17 . This is almost twice the expected $\mathrm{CH}_{4}$ emission from such a cow. High $\mathrm{CH}_{4}: \mathrm{CO}_{2}$ can be due to high $\mathrm{CH}_{4}$ or low $\mathrm{CO}_{2}$, the latter potentially indicating high feed efficiency. The coefficient of variation of the $\mathrm{CH}_{4}: \mathrm{CO}_{2}$ ratio in van Engelen et al. (2018) was 0.71, which is about 5 -fold greater than that reported by Aubry and Yan. (2015). Unrealistic mean and SD values suggest serious problems with use of the sniffer method for measuring enteric $\mathrm{CH}_{4}$ emissions in the study of van Engelen et al. (2018). With such high SD values, most of the variation is due to random errors in measurements. Head position, sampling distance, and exhalation rate affect the $\mathrm{CH}_{4}: \mathrm{CO}_{2}$ ratio less than they affect $\mathrm{CH}_{4}$ concentration, but interpretation is not straightforward; a high $\mathrm{CH}_{4}: \mathrm{CO}_{2}$ ratio can also result from high feed efficiency (low $\mathrm{CO}_{2}$ production). For example, the coefficient of variation for $\mathrm{CH}_{4}$ yield ( $\mathrm{g}$ of $\mathrm{CH}_{4} / \mathrm{kg}$ of DMI) for a large European data set of individual cow observations was $16 \%$ (Niu et al., 2018). In reality, selecting for low emissions can result in selecting for reduced DMI or poor efficiency of cell-wall digestion. It could be argued that the shortcoming of poor efficiency of cell-wall digestion could be solved in a breeding index. However, this may not be possible because increased digesta passage rate from the rumen is the main animal factor influencing $\mathrm{CH}_{4}$ yield. In this case, maintaining cell-wall digestibility requires that the digestion rate increases, which is unlikely because digestion rate is a feed characteristic, not an animal characteristic. We conclude that true between-cow variation in $\mathrm{CH}_{4}$ emissions is too small to be reliably measured by the sniffer method with its low precision.

\section{REFERENCES}

Aubry, A., and T. Yan. 2015. Meta-analysis of calorimeter data establish relationships between methane and carbon dioxide emissions or oxygen consumption for dairy cattle. Anim. Nutr. 1:128-134. https://doi.org/10.1016/j.aninu.2015.08.015.

Hammond, K. J., L. A Crompton, A. Bannink, J. Dijkstra, D. R. Yanez-Ruiz, P. O'Kiely, E. Kebreab, M. A. Eugene, Z. Yu, K. J. 
Shingfield, A. Schwarm, A. N. Hristov, and C. K. Reynolds. 2016. Review of current in vivo measurement techniques for quantifying enteric methane emission from ruminants. Anim. Feed Sci. Technol. 219:13-30.

Huhtanen, P., E. H. Gabezas-Garcia, S. Utsumi, and S. Zimmerman. 2015. Comparison of methods to determine methane emissions from dairy cows in farm conditions. J. Dairy Sci. 98:3394-3409. https://doi.org/10.3168/jds.2014-9118.

Niu, M., E. Kebreab, A. N. Hristov, J. Oh, C. Arndt, A. Bannink, A. R. Bayat, A. F. Brito, T. Boland, D. Casper, L. A. Crompton, J. Dijkstra, M. A. Eugène, P. C. Garnsworthy, M. N. Haque, A. L. F. Hellwing, P. Huhtanen, M. Kreuzer, B. Kuhla, P. Lund, J. Madsen, C. Martin, S. C. McClelland, M. McGee, P. J. Moate, S. Muetzel, C. Muñoz, P. O'Kiely, N. Peiren, C. K. Reynolds, A. Schwarm, K.
J. Shingfield, T. M. Storlien, M. R. Weisbjerg, D. R. Yáñez-Ruiz, and Z. Yu. 2018. Prediction of enteric methane production, yield and intensity in dairy cattle using an intercontinental database. Glob. Chang. Biol. https://doi.org/10.1111/gcb.14094.

van Engelen, S., H. Bovenhuis, P. P. J. van der Tol, and M. H. P. W. Visker. 2018. Genetic background of methane emissions by Dutch Holstein Friesian cows measured by infrared sensors in automatic milking system. J. Dairy Sci. 101:2226-2234. https://doi.org/10 $.3168 /$ jds.2017-13441.

Wu, L., P. W. G. Groot Koerkamp, and N. Ogink. 2018. Uncertainty assessment of the breath methane concentration method to determine methane production of dairy cows. J. Dairy Sci. 101:15541564. https://doi.org/10.3168/jds.2017-12710. 